\title{
MODEL ON NATURAL SCIENCES SUBJECT (IPA) GRADE IV ELEMENTARY SCHOOL
}

\author{
Shendi Kharisma Widiastuti 1,*, Sumardjono PM 2 \\ 1,2 Faculty of Teacher Training and Education. UKSW
}

\begin{abstract}
This study aimed to produce a product namely learning media in the form of flashcardon the theme of "Tempat Tinggalku" for elementary school students grade IV which suit for use and in accordance with the needs of students and to improve student learning outcomes. This type of research was research development (research and development). The initial product that has been created through the validation process is done by the learning media experts and subject matter experts. Furthermore, this product was tested to students through two stages namely, limited trials and extensive trials. The limited trial subjects consisted of 10 fourth graders of elementary school, and 36 students in extensive trials. Other data collected in this study was the response of teachers, students' response and students' learning outcomes after using flashcard media. The average result of students' written test on pretest was 51.86 while the post test was 87.28 . This proves that there is significant increase of learning outcomes that was equal to 35,42 . These results come from written tests before students used the media and after using the learning media. The average result of student learning outcomes increased after they participated in the learning activity by using flashcard media.
\end{abstract}

Keywords:

Problem Based Learning,

Flashcard, Learning

outcomes

\section{Introduction}

Each child is progressing in his life through some stages - one by one, when growing up a child has different needs - different. Even so, every child still needs time to play while learning, this activity can be started since the child enters the age of the toddler informally. This is done by some parents who realize the importance of child growth to start playing while learning, every child can be accompanied by parents and can be done at home using various media available. As for children who have entered the age of 6 years, learning while playing can be done at school and accompanied by teachers. At this stage children enter formal schools that have a curriculum as a guide to understand the material and can achieve goals in basic education.

Children at the elementary school level have not been able to think abstractly to understand learning materials. At the age of elementary school, children enter the concrete operational stage, ie for age of 7 to 12 years. According to (Piaget \&Inhelder), "... they relate directly to objects and not yet to verbally stated hypotheses" (they are directly related to the object and have not received a verbal explanation).

In the delivery of subject matter, teachers at the school have not involved many students in the learning process. The teacher must change his or her mindset to be able to meet the needs of this developed age, such as become facilitator in the learning process. Teachers' duties are not only deliver the learning materials but also must be able to change the learning atmosphere to be active, fun, and comfortable. Students need to be involved in the learning process in order to be trained to be able to explore, recognize and explore their potential respectively and dare to express opinions in public well.

On learning model of Problem Based Learning, students can learn through the problems they face in daily life - today. Students are stimulated to be able to analyze the problems that occur in the environment. This learning model is centered on the students, so it has benefits for individuals as well as for groups.

Problem Based Learning include (1) group activities, namely reading cases; determine which issues are most relevant to the learning objectives; Make the outlineof the problems; make hypothesis; 
identify sources of information, discussions, and task-sharing; and reporting, discussing the possible problem solution, reporting the progress made by each group member, as well as presentation in the class; (2) individual activities, ie students perform reading activities of various sources, researching, and delivering the findings; And (3) classroom activities, ie presenting reports, and discussions between groups under the guidance of teachers. (Rusmono, 2012)

The research result that made as reference of this study that is the research that conducted (Sari, 2014) entitled "Improving Reading Skills ThroughFlash Cards Media in Indonesian Language Subject for Elementary School Students Grade I SDN 2 Ngroto Gubug Grobogan School Year 2013/2014". The second study is the research (Nurhikmah, 2012) with the title "The Effectiveness of Problem Based Learning (PBL) Implementation Model in Improving the Quality of Natural Science Learning of Grade V Students of Adiwerna 04 State Elementary School Tegal Regency" The third research result by ( Ikasari, 2013) who has been utilized " The implementation of Model Make a Match with Flashcard Media in Learning Natural Science to Improve Activities of Grade VB Students of SD Islam Al Madina. "And the result of research (Wulandari, 2015) with the title" the Effect of Application of Problem Based Learning on the Independence of Natural Science Class Students Grade IV SD Group III , Temon District, KulonProgo Regency ". The conclusion of this research are : 1) Use of flashcard can improve students' skills .; 2) Use of flashcard can increase students' activity.; 3) Improving student learning outcomes 4) there is a significant positive effect of being independent learning natural science

Through this research, the teachers are expected to utilize the flashcard as the media in the learning process to improve the process and learning outcomes of the students in science subjects.

\section{Method}

Researcher chose the method of research and development or commonly called the Research and Development (RnD). To produce and test the effectiveness of the products, the $R n D$ research method can be used (Sugiyono, 2015). The development model that conducted to develop the resulting product was a procedural model. This was done so that the product can be according to the needs in the classroom so that in its use can be more optimal, in this study developed flashcard learning product with model of problem-based learning.

Problem based learning model was chosen by researcher because it was appropriate if used in both class of individuals and small groups form such as dividing students into some groups. Problem based learning model can hone the skills of students individually through the group that was formed because students can put themselves into groups to work together. Students can establish good communication and socializing with friends in the class thoroughly and make friendships with other students.

This research was conducted in April - June at SD Negeri 02 Dukuh Salatiga. The subjects were a fourth grade student at SD Negeri 02 Dukuh Salatiga, amounting to 36, this school used the 2013 curriculum in the learning process. These subjects used learning media in the form of flashcards. A limited trial was conducted with the subjects of 10 students, while the extensive trial with subjects of 36 students.

Researcher used procedural model which means that this model was descriptive and has several steps that must be followed to be able to produce the desired product. Research and development will result in the form of flashcard learning media.

The development model used was the development model according to (Sugiyono, 2015), the steps - steps were: (1) Potentials and problems, the first step i.e the researcher did observation at SDN 02 DukuhSalatiga, the place of research is class IV; (2) Gathered information, the researcher collected data to be used as material for planning; (3) Product design, at this stage the researcher made learning media in the form of flashcards; (4) Design validation, once the media was created, the researcher performed the assessment as a way to validate the media to determine the feasibility of the media used. This was done by media experts, judging by the design of learning media and materials taught; (5) Design improvement, after the assessment of the media learning experts, then the media was correctedd or revised; (6) Product trials, this trial was conducted to determine the weaknesses and deficiencies in the media. Researcher used questionnaires to collect data on the media that was being developed; (7) Product revisions, this stage was performed after conducted product trial, and analyze the data that has been collected to improve the media; (8) The test user, in this test, flashcard media will be used in the learning process with the theme of TempatTinggalku; (9) Product revisions, in this revision learning media would be improved again if there were deficiencies in the product, for better result; (10) Preparation in bulk, the final result of learning media developed based on the validation, revision, and product test conducted later published.

The procedure steps of learning media development in the form of flashcard conducted by researcher described as follows: (1) the data collection stage, this stage was conducted to determine the 
needs of learning in the field by means of field studies and literature. (a) Field studies were conducted to find out the need for learning resources in primary schools. Field studies were conducted by means of curriculum analysis in school, student development analysis, and analysis of the availability of learning resources in the field. (b) Literature study on theories relating to learning resources with the theme of TempatTinggalku on the fourth grade of elementary school; (2) The planning stage, a stage which started by conducted the making of the design planning flashcardtempattinggalku to expand the concept of information in the fourth grade students. After the design was established, then mapping of learning materials will be delivered for reinforcement. Material mapping started with the analysis of Core Competency (KI) and Basic Competence (KD) and formulated objectives and indicators in the delivery of materials. At this planning stage of planned evaluation of learning resources was by making the grid assessment; (3) Product development stage, this stage started with material collection, materials management, and the last was production. (4) The stages of validation and testing, learning media that have been produced and then evaluated. The form of the evaluation of the flashcard learning media product was validation. Validation was done in two stages. The first stage was validation by media experts and material experts, through this stage obtained the feasibility of data product and advice from media experts and material experts. The suggestion was then used for the first-stage product revision. The first stage revision result used for second validation by the teacher, suggestions from the teacher are used for the second revision. The results of both revisions are used for trials used by students. The results of this trial were in the form of student responses to the flashcard learning media.

In this study the researcher used data collection techniques through the validation of media experts and materials, tests, and non-test in the form of questionnaires. The validation of experts have goal whether flashcard learning media were worthy to use. Aspects assessed include the suitability of the completeness of the material with the indicator material, product display, design, and the effectiveness of learning media in its use.

At this stage the product exposure was seen to determine the effectiveness, efficiency, and attractiveness of the resulting product. It was associated with the design of learning media and test subjects. Researcher conducted test to collect data that can be done on subjects in activities by making small group formation.

Other data collected by researcher to find out the opinion of teachers with non-test techniques through questionnaires. This was done to determine the quality of learning media that produced.

The researchers collected data on the products used from the students through questionnaires and observations. This technique was non-test technique to determine the quality of the flashcard learning media that has been produced. This was done to determine the extent to which the resulting product was useful for students, and to know the response of students on the products used. While the observation was conducted to determine the extent to which teachers and students used this flashcard media in learning activities.

The instruments used in this research were: (1) The validation sheet used by media experts and materials covering the suitability of the illustration with the subject matter. The suitability of illustrations with real life was necessary so that students can be interested and more understand about the learning materials. (2) teacher questionnaires response, were questionnaires with closed questions addressed to teachers to test the feasibility of learning media. Teacher assessment was given in accordance with the criteria that demonstrate how worthy the flashcard media used in learning. (3) Student opinion sheets in the form of questionnaires with closed question model concerned with learning media used. The student response questionnaires were needed by researcher to see the interest of students in following the learning activities. Some aspects were assessed in terms of learning media content, display aspects, and aspects of use. Another thing that can be seen from the students' questionnaires were the ease of using flashcard media so that students easily understand the lesson and were interested to learn. (4) Observation sheets, observation of activities conducted to observe the implementation of teaching and learning activities using learning media in the form of flashcards. This sheet used to assess the extent or how well teachers use flashcard media in delivering the subject matter.

Criteria for assessment of validation sheets, teacher questionnaires, and observation sheets can be seen in table 1 .

Table 1. Assessment Criteria

\begin{tabular}{cc}
\hline Score & Criteria \\
\hline 1 & Very unsuitable \\
2 & Not suitable \\
3 & Suitable enough \\
4 & Suitable \\
\hline
\end{tabular}




\begin{tabular}{cc}
\hline Score & Criteria \\
\hline 5 & Very suitable \\
\hline
\end{tabular}

Data analysis techniques were done in two stages, namely through quantitative and qualitative analysis. To determine the validity of a media used measurement scale, then conducted the conversion of quantitative score. The convertion of scores conducted on data that used Likert scale with the weight of predetermined scores of 1,2,3,4, and 5. According to (Gonia, 2009) this data in the form of quantitative data which will then be analyzed descriptively. To calculate this data, (Sugiyono, 2009) explained that must determine the ideal score first. Ideal score or also can be called a criterion is a score set by assuming that all respondents gave the highest score on each item of questions. Then, conducted division between the total score of data collection results with the ideal score.

The formula of the calculation score can be seen below. The calculation of rating scale according to (Sugiyono, 2009) was determined by the following formula:

Information :

$$
P=100 \% \frac{\text { data collecton result score }}{\text { ideal score }}
$$

$\mathrm{P}=$ percentage figures

Ideal score $=$ highest score per item $\times$ number of respondents $\times$ number of items

According to (Gonia, 2009) the level of media validation was divided into four categories, which can be seen in table 2 interpretation of the assessment as follows.

Table 2. Intepretation of Assessment Category

\begin{tabular}{cc}
\hline Percentage (\%) & Interpretation \\
\hline $0-25$ & Not good \\
$25-50$ & Not very good \\
$50-75$ & Good \\
$75-100$ & Very Good \\
\hline
\end{tabular}

To find out the effectiveness of the media flashcard, students were asked to do a written test. There were two tests that were pretestconducted before students learn to use medical learning. Then, thesecond was written test i.eposttest conducted when students were already participating in learning activities using flashcard media. To obtain the data, an analysis of pretest and posttest results was tested using paired sample t test (Paired Sample T-Test). Before performing the paired sample t test should perform the normality test, if the data was normally distributed then the test $t$ test can be done. If one or both of the data were not normally distributed, then non-parametric test can be done or commonly called the Wilcoxon test

\section{Results And Discussion}

\section{Description of Development}

Many stages which were conducted in this research were, the step of collecting the data with field studies and literature review. The field studies were done to find out the information about implementing learning using curriculum of 2013. In the stage of field survey, the activity was interview and observation about obstacles and availability of learning media at school.

The finding data was used as the material for doing the plan to design initial media product of flashcard. After the initial product was done, it would be validated by media and material expert. The suggestion from the media expert were used to revise the product. Then, the researcher did limited examination for 10 students in IV grade SDN 02 DukuhSalatiga by using Problem Based Learning (PBL) model. After doing the limited examination, the students answer the questioner and did the writing test to find out the success of the product. The next step was revising the product as the answer in the questionnaire of students and teacher's which were used in previous learning.

The revised product was used in extensive trials in 36 students and it was needed feedback such as observation sheet, questioner of teaches and students' response and the result of writing test. The result was used to revise the used product in previous learning activity. The result of writing test which had already done the validation test would use to find out the success of learning media od flashcard.

Based on interview result with the teachers, the students were more enthusiastic in learning activity when the teachers used learning media. The teachers usually made learning media which was 
easy to make or the learning media that was already available at school. The obstacles that were found by the teachers were the school did not have the media as the taught material that was suitable with the curriculum. In addition, the teachers had no spare time to make the interesting and fun learning media to explain the material to the students.

\section{Developing of The Media}

Based on the information, learning media was very needed to explain subject matter especially support media from the teacher which was suitable with basic competencies and learning indicator. Developing media like flashcard could make the students were more interested because it has colors. Flashcard media about waste disposal was adjusted with basic competences which was the relation between natural resource with the environment, technology and people. In addition, the picture of flashcard was suitable with the real daily condition that was known by the students.

\section{Validation from The Expert}

The initial product which had made was given to material and media expert to be validated. Many research about media covered material aspects and media design, it was also given the suggestion column to fix the media. The suggestions from the media and material expert toward the initial product were: (1) the picture of the river should be enlarged; (2) The children who throw the garbage should be a girl and a boy. The revised product was adjusted with suggestion from media and material validator. The picture of the river was not big, as the suggestion from the validator, the picture should be enlarged in order to make the student focus on the river. In the initial product of the flashcard, the picture showed a girl thrown the garbage, as the suggestion from the validator, it should be added the picture of a boy who thrown the garbage. This was done to not make the assumption that the girl gave the bad example because she thrown away the garbage to the river. The data that was obtained from the expert was questioner which cover the media score and learning material could be checked in table 3 and 4.

Table 3. of Validation Result from Media Expert

\begin{tabular}{lc}
\hline \multicolumn{1}{c}{ Indicator } & Score \\
\hline $\begin{array}{l}\text { Illustration suitability in representing } \\
\text { the material } \\
\begin{array}{l}\text { The example of material relation with } \\
\text { the environment }\end{array}\end{array}$ & 5 \\
$\begin{array}{l}\text { The illustration suitability in giving the } \\
\text { example in the real life }\end{array}$ & 5 \\
$\begin{array}{l}\text { The media ability to make the students } \\
\text { to be more active }\end{array}$ & 5 \\
$\begin{array}{l}\text { Interesting and stimulating the students } \\
\text { to understand the material } \\
\text { The quality of situation or issues in the }\end{array}$ & 5 \\
illustration \\
$\begin{array}{l}\text { Easy to use and treated } \\
\begin{array}{l}\text { The design and the size of the media } \\
\text { The choice of the colors }\end{array}\end{array}$ \\
$\begin{array}{l}\text { The clarity of the pictures and } \\
\text { illustration }\end{array}$ & 5 \\
\hline
\end{tabular}

Table 4. The Acquisition from Media Expert

\begin{tabular}{c}
\hline $\mathrm{P}=100 \% \frac{\begin{array}{c}\text { Criteria } \\
\text { The result scoe of collecting } \\
\text { the data }\end{array}}{\mathrm{P}=100 \% \frac{\text { idea score }}{4 \times 1 \times 10}}=94 \%$ \\
$\begin{array}{c}\text { explanation: } \\
\text { Ideal Score }=\text { the highest score in each item } \times \text { the }\end{array}$
\end{tabular}




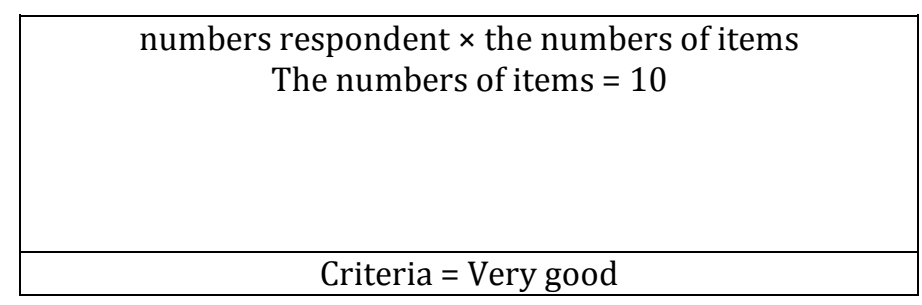

The result criteria of media validation were very good to use, however, it needed to revise as the suggestions from media expert. The assessment validation media item covered the convenience of saving and treating learning media. The clarity of illustration and picture and also the relation with the daily lives of the students, so that the students could understand the meaning of the learning media.

The material validation indicator items covered 10 items which included adjustment of media with learning material. In addition, the assessment toward the learning purpose by using media and using the learning model were also written in assessment item indicator. The result of material from the expert's validation could be checked on table 5 and 6 .

Table 5. of Validation result from Material Expert

\begin{tabular}{lc}
\hline \multicolumn{1}{c}{ Indicator } & Score \\
\hline $\begin{array}{l}\text { The Adjustment of media and learning } \\
\text { indicator }\end{array}$ & 5 \\
$\begin{array}{l}\text { The adjustment of media with learning } \\
\text { purpose }\end{array}$ & 5 \\
$\begin{array}{l}\text { The adjustment of media and taught } \\
\text { material }\end{array}$ & 4 \\
$\begin{array}{l}\text { The adjustment of illustration in } \\
\text { representing the material }\end{array}$ & 5 \\
$\begin{array}{l}\text { The adjustment of illustration in giving } \\
\text { the example of real life }\end{array}$ & 5 \\
$\begin{array}{l}\text { The adjustment of material example } \\
\text { and environment }\end{array}$ & 5 \\
$\begin{array}{l}\text { The accuracy in using learning model } \\
\text { The consistency of evaluation and }\end{array}$ & 5 \\
$\begin{array}{l}\text { learning purpose } \\
\text { To interest and stimulate the students } \\
\text { to learn }\end{array}$ & 4 \\
The easy of being understood & 4 \\
\hline
\end{tabular}

Table 6 the Assessment score from material expert

\begin{tabular}{c}
\hline $\mathrm{P}=100 \% \frac{\begin{array}{c}\text { Criteria } \\
\text { the result score of collecting } \\
\text { the data }\end{array}}{\text { idea score }}$ \\
$\mathrm{P}=100 \% \frac{47}{5 \times 1 \times 10}=94 \%$ \\
$\begin{array}{c}\text { Ideal Score }=\text { the highest score in each item } \times \\
\text { the numbers respondent } \times \text { the numbers of } \\
\text { items }\end{array}$ \\
The numbers of items $=10$ \\
Criteria = Very good
\end{tabular}

\section{The Description of Product Trial}

The limited trial was done after the researcher revised initial product as the suggestion from material and media validators. The limited trial was done with 10 students in SDN 02 Dukuh Salatiga on 5 June 2017. The obtained data was the questionnaire respond from the teacher and students, observation 
sheet during the teacher was teaching and the result of written test. The data of the respond from the teacher was in table 7 and 8.

Table 7 The Result of Teacher's Respond

\begin{tabular}{lc}
\multicolumn{1}{c}{ Indicator } & Score \\
\hline $\begin{array}{l}\text { The adjustment of flashcard media } \\
\text { with learning indicator }\end{array}$ & 5 \\
$\begin{array}{l}\text { The adjustment of flashcard media } \\
\text { with material concept which was } \\
\text { taught }\end{array}$ & 5 \\
$\begin{array}{l}\text { The adjustment of flashcard media } \\
\text { with learning purpose }\end{array}$ & 4 \\
$\begin{array}{l}\text { The students were enthusiast } \\
\text { following the learning activity }\end{array}$ & 4 \\
$\begin{array}{l}\text { Media helped the students to get good } \\
\text { learning experience }\end{array}$ & 3 \\
$\begin{array}{l}\text { The learning using media made the } \\
\text { students are more creative and active }\end{array}$ & 3 \\
$\begin{array}{l}\text { The learning used media increase the } \\
\text { curiosity of students }\end{array}$ & 4 \\
$\begin{array}{l}\text { The learning used flashcard media } \\
\text { became easier }\end{array}$ & 5 \\
$\begin{array}{l}\text { The pictures of flashcard media were } \\
\text { easy to understand }\end{array}$ & 5 \\
$\begin{array}{l}\text { The size of flashcard media had been } \\
\text { good }\end{array}$ & 5 \\
\hline
\end{tabular}

Table 8 The Assessment Result of Teacher's Respond

\begin{tabular}{c}
$\begin{array}{c}\text { Criteria } \\
\text { The result score of collecting } \\
\text { the data }\end{array}$ \\
$P=100 \% \frac{43}{\text { idea score }}$ \\
$P=100 \% \frac{5 \times 1 \times 10}{5 \times 1}=86 \%$ \\
Ideal Score $=$ the highest score in each \\
item $\times$ the numbers respondent $\times$ the numbers \\
of items \\
The numbers of items $=10$ \\
\hline Criteria = Very good
\end{tabular}

The collecting data was the result of writing test which is pretest score that were done before students used flashcard media. Then posttest was done after the students do the learning activity using flashcard media. The result score of pretest and posttest can be seen on graphic 1 and 2 .

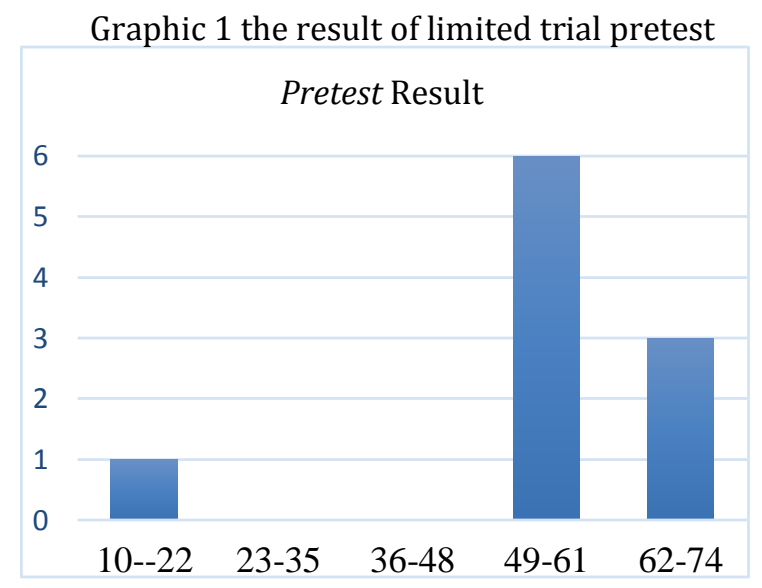


Graphic 2 limited trial posttest result

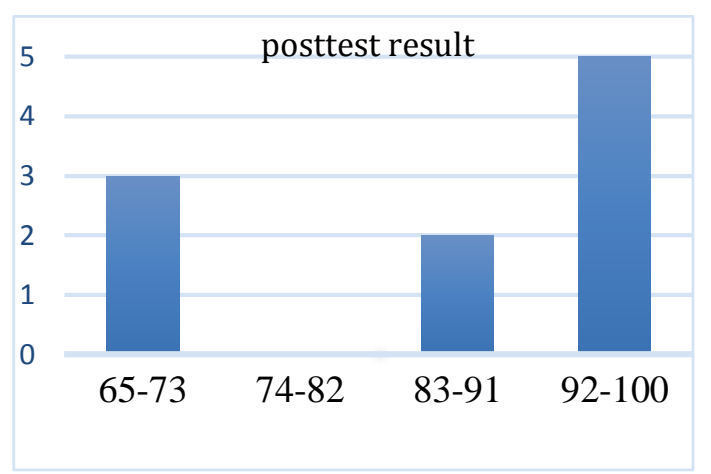

Based on the data of students respond toward the media, 8 students agreed that flashcard media made them interest to follow the material. In the second indicator, 9 students agreed using flashcard media eases them to study. In the third indicator, 9 students agreed that the pictures in media made them more interested to pay attention to the teacher's explanation. In the fourth indicator, 9 students agreed that they were more active following the material using flashcard. In fifth indicator, 10 students agreed that flashcard was really easy to use. The result of student's respond was in table 9.

Table 9 Result of Students' Respond

\begin{tabular}{lcc}
\hline \multicolumn{1}{c}{ Indicator } & Yes & NO \\
\hline $\begin{array}{l}\text { Flashcard media made the students interested } \\
\text { following the material }\end{array}$ & 8 & 2 \\
$\begin{array}{l}\text { Using the media made easy to study } \\
\begin{array}{l}\text { The pictures in te flashcard made the students } \\
\text { were more interested paying attention to the }\end{array}\end{array}$ & 9 & 1 \\
$\begin{array}{l}\text { teachers'explanation } \\
\begin{array}{l}\text { The learning activity using flashcard made the } \\
\text { students more active in studying } \\
\text { flashcard media was very easy to use }\end{array}\end{array}$ & 9 & 1 \\
\hline
\end{tabular}

The teacher's data was not only from questionnaire but also observation sheet of learning activity. The numbers of assessment items consist of 11 indicators, score in observation sheet could be seen on table 10 and 11 .

Table 10 Learning Observation Result

\begin{tabular}{lc}
\hline \multicolumn{1}{c}{ Aspects } & Score \\
\hline $\begin{array}{l}\text { Preparing small flashcard for students } \\
\begin{array}{l}\text { Setting the seats so that the students could look at } \\
\text { the big flashcard clearly }\end{array}\end{array}$ & 4 \\
$\begin{array}{l}\text { Explaining learning material that was suitable with } \\
\text { SK, KD, purpose and indicators }\end{array}$ & 5 \\
The teacher took over the class & 3 \\
$\begin{array}{l}\text { Giving the clear instruction before starting the game } \\
\text { Facilitating the students to use flashcard }\end{array}$ & 5 \\
$\begin{array}{l}\text { Open behave to all questions and student's respond } \\
\text { Using the easy language to make the students }\end{array}$ & 4 \\
$\begin{array}{l}\text { understand } \\
\text { The students played using flashcard } \\
\text { Doing the reflection }\end{array}$ & 5 \\
Giving the evaluations to the students & 5 \\
\hline
\end{tabular}


Table 11The Assessment Result of Teacher's Observation

\begin{tabular}{|c|}
\hline $\begin{array}{c}\text { Criteria } \\
\text { Result score of collecting } \\
\text { the data }\end{array}$ \\
$\mathrm{P}=100 \% \frac{48}{\text { ideal score }}$ \\
$\mathrm{P}=100 \% \frac{4 \times 11}{5 \times 1 \times 1}=87 \%$ \\
$\begin{array}{c}\text { Ideal Score }=\text { the highest score in each item } \times \\
\text { the numbers respondent } \times \text { the numbers of } \\
\text { items }\end{array}$ \\
The numbers of items $=11$ \\
Criteria $=$ Very Good
\end{tabular}

Based on the score on the table above, the teacher agreed that the aspects activity was done in learning activity. The average score showed the result that the learning activity run very well.

Extensive trial was done after limited trial with the more numbers. The numbers of students who did extensive trial were 36 students on 7 Jun 2017. Before the learning activity using the media was started, the students did pretest. After they were done the pretest, they did learning activity using flashcard. In the extensive trial, the result data was observation sheet, questionnaire of teacher's and students' respond and the result test of class IV. The result and pretest and extensive trial posttest could be seen in graphic 3, 4 and table 12 .

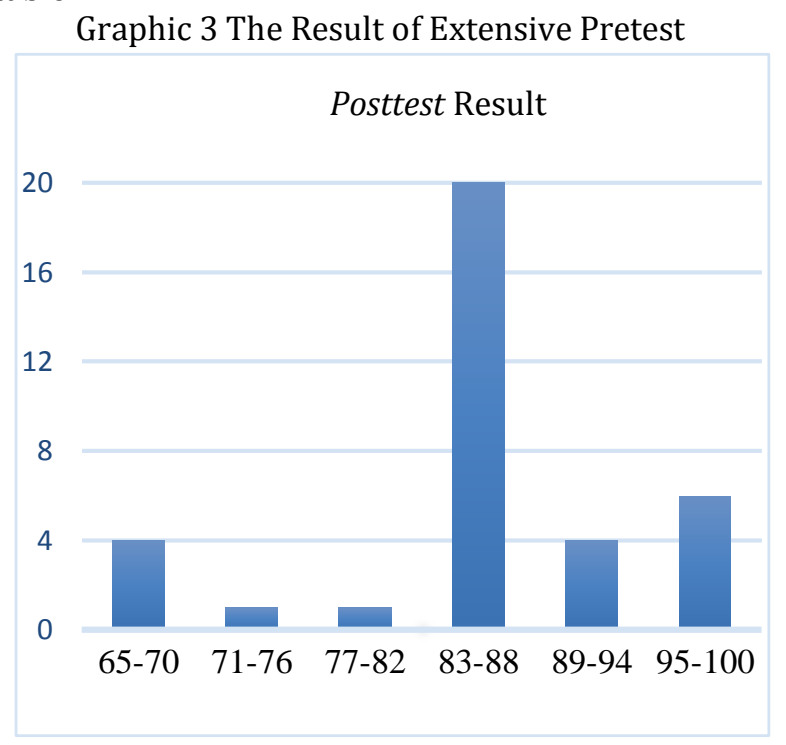

Graphic 4 The Result of Extensive Posttest

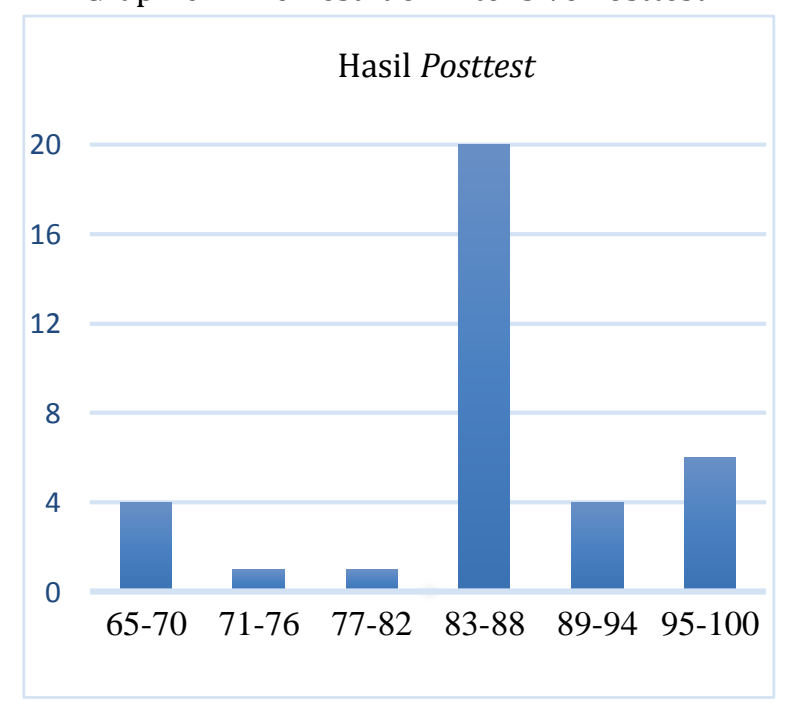


Table 12 The Result Data of Extensive Trial

\begin{tabular}{ccc}
\hline Score & Pretest & Posttest \\
\hline Highest & 22 & 67 \\
Lowest & 94 & 100 \\
Average & 51,86 & 87,28 \\
\hline
\end{tabular}

On the table above, it could be known that the lowest score of pretest was 22 and the highest score was 94 with the average score was 51,86. Whereas the lowest score of posttest was 67 and the highest score was 100 with the average was 87,28 . The increasing score and average of the students according to the graphic 4 and 5. The score was obtained from the writing test before using flashcard media and after using flashcard media in learning activity. The result of comparing the increasing average in writing test could be seen in graphic 5 .

Graphic 5 The Increasing Average

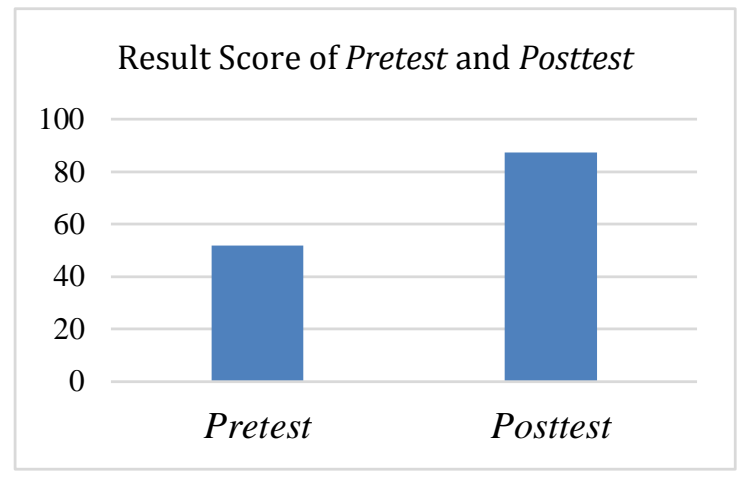

In the student's respond, it could be known the students who agreed that learning activity with media was fun, easy and more interested and made them more active. The respond of the students could be seen in table 13 .

Table 13 The Result of Students Respond

\begin{tabular}{lcc}
\hline \multicolumn{1}{c}{ Indicator } & YES & NO \\
\hline $\begin{array}{l}\text { Flashcard media made them interested join the } \\
\text { learning activity }\end{array}$ & 34 & 2 \\
$\begin{array}{l}\text { Using media made them easier to study } \\
\begin{array}{l}\text { The pictures in flashcard made them interested } \\
\text { to pay attention to the teacher's explanation }\end{array}\end{array}$ & 33 & 3 \\
$\begin{array}{l}\text { Learning activity using flashcard made the } \\
\text { students are more active in studying } \\
\text { Flashcard media was very easy to use }\end{array}$ & 34 & 2 \\
\hline
\end{tabular}

The students' respond could be seen in graphic 6 .

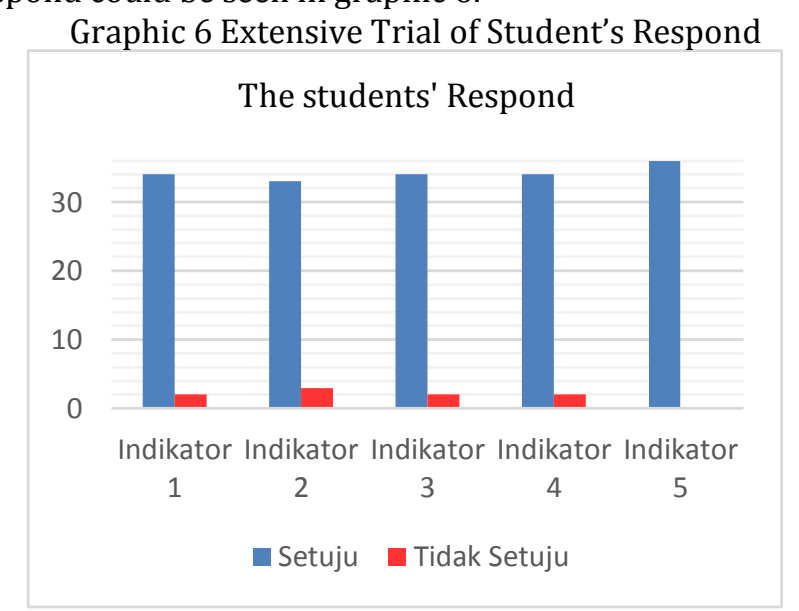


Table 14. Pretest Reliability

\begin{tabular}{cc}
\hline Cronbach's Alpha & N of Items \\
\hline .654 & 18 \\
\hline
\end{tabular}

From the data, it could be known that there were 34 students were more interested to the learning by using flashcard and there were 2 students who disagreed. There were 33

students felt easier to study with the media and 3 students disagreed. The picture in flashcard interacted the students to pay attention teachers' explanation was shown the acquisition of 34 students and 2 students disagrees. There were 34 students felt more active in following the material and 2 students disagreed. All student agreed that flashcard was very easy to use in learning activity, it was shown by 36 students.

The assessment criteria of media and material which were shown to the students would show the appropriateness of flashcard media to use in learning activity. The extensive trial was also used to know flashcard media effectiveness in increasing students' score.

The analysis result of pretest and posttest was examined statistically by using normality and reliability test. The normality test was done to know whether the data had normal distribution or not. Realibility test was done to know whether the reliable data to use as writing test.

Table 15 Posttest Reliability

\begin{tabular}{cc}
\hline Cronbach's Alpha & N of Items \\
\hline .330 & 18 \\
\hline
\end{tabular}

The result of pretest and posttest reliability was compared with the score of $r$ table $=0.329$ because the numbers of student were 36 children. In the column Cronbach's Alpha, the pretest result was 0.654 bigger $>$ if it was compared with 0.329 which meant pretest questions could be reliable to use as measurement. Whereas, the column of Cronbach's Alpha pretest was 0.330 bigger $>$ than 0.329 so that the questions of posttest were also reliable to use as the measurement.

Table 16. Normality Test

\begin{tabular}{lccc}
\hline & \multicolumn{3}{c}{ Shapiro-Wilk } \\
\hline & Statistic & $\mathrm{df}$ & Sig. \\
\hline Pretest & .943 & 36 & .063 \\
Posttest & .924 & 36 & .017 \\
\hline
\end{tabular}

a. Lilliefors Significance Correction

In the result of saphiro-wilk significance column showed the score of the pretest was 0.063 and the posttest score was 0.017 . the pretest showed the bigger significance from 0.05 so the pretest score had normal distribution. Whereas the significance of posttest was less than 0.05 so that result of the posttest was not normal. If there was unnormal result, to compare the test result had to be done Wilcoxon test. The result of Wilcoxon test using SPSS 16.0 could be checked to this table below.

Table 17 The Rate of Wilcoxon Test

\begin{tabular}{ccccc}
\hline & & N & Mean Rank & Sum of Ranks \\
\hline Posttest - & Negative Ranks & $1 \mathrm{a}$ & 1.00 & 1.00 \\
Pretest & Positive Ranks & $35 \mathrm{~b}$ & 19.00 & 665.00 \\
& Ties & 0c & & \\
& Total & 36 & & \\
\hline
\end{tabular}
a. Posttest < Pretest
b. Posttest $>$ Pretest

Negative ranks between pretest and posttest was 1, which meant there was a student that experienced score decreasing. Positive ranks between pretest and posttest, there were 35 students experienced increasing result test. The mean rank was 19 , whereas sum of rank was 665 . The same score 
of pretest and posttest got 0 , which meant the score between pretest and posttest do not have the same score.

Based on statistic test in table 14, it was known that the significance score was 0.000 which smaller than 0.05. so, it could be concluded that there was difference between pretest and posttest so it could draw the conclusion that using flashcard media could influence the students' result of learning in class IV.

Table 18 Statistic Output

\begin{tabular}{lr}
\hline & Posttest - Pretest \\
\hline $\mathrm{Z}$ & $-5.222 \mathrm{a}$ \\
Asymp. Sig. (2-tailed) & .000 \\
\hline a. Based on negative ranks. & \\
b. Wilcoxon Signed Ranks Test
\end{tabular}

\section{Discussion}

The effectiveness of flashcard media could be seen from the average result of pretest score which increased on posttest. Flashcard media was effective to use as the media in learning activity according to analysis result which had done. The numbers of flashcard were 7 units, the pictures related each other. In the flashcard, it depicted the clean environment and it changed when two children thrown away the garbage into the river and it caused the clogged river. When it was rain, the water of river overflow because there was many garbage were clogged so that it caused floods. This flashcard was used as the media by the teacher to explain the material about waste processing. The pictures were relevant with the real condition in many cities that students could directly see or watch through the television. The flashcard was expected to be able to make the students were more active and interested to study and pay attention to their teacher.

\section{Conclusion}

Based on the result and discussion of developing learning media of flashcard has through 6 steps: (1) doing the field research, (2) doing the literature review, (3) planning the draft of the product, (4) doing the validation, (5) doing the revising and (6) doing the trial. The research produces learning media like flashcard for the science subject in IV grade of elementary school which is suitable with basic competence and the learning indicator. The quality of developing media is very good according to the criteria in the table.

Referring to the result of the research which is done, that flashcard media eases the students in understanding the subject material so it can be suggested: (1) the usage of flashcard media makes the students are more interested to pay attention the teacher's explanation and they are more active in following the learning. (2) the teacher can use flashcard as the alternative of learning activity so that the students will more understand the material. (3) The teacher can use other alternative game in using flashcard so that all students can participate to active in learning activity.

\section{References}

Gonia, M. F. (2009). Pengembangan Multimedia Interaktif Untuk Asesmen Pembelajaran. Bandung: UPI. Piaget, J., \& Inhelder, B. (n.d.). The Psychology Of The Child. New York: Basic Books, Inc.

Rusmono. (2012). Pembelajaran dengan Problem Based Learning itu Perlu. Jakarta: Ghalia Indonesia.

Sugiyono. (2009). Metode Penelitian Pendidikan (Pendekatan Kuantitatif, Kualitatif, dan R\&D). Bandung: Alfabeta.

Ikasari, A. E. (2013, 06 20). Penerapan Model Make a Match dengan. Retrieved 04 02, 2017, from http://lib.unnes.ac.id/17 079/1/1401409167.pdf

Nurhikmah. (2012, Juli). Keefektifan Penerapan Model Problem Based Learning (PBL) terhadap Peningkatan Kualitas Pembelajaran Daur Air Siswa Kelas V Sekolah Dasar Negeri Adiwerna 04 Kabupaten Tegal. Retrieved from http://lib.unnes.ac.id/18193/1/1402408298.pdf

Sari, N. S. (2014, Februari 28). Peningkatan Kemampuan Membaca Melalui Media Flash Card Pelajaran Bahasa Indonesia. Retrieved from http://eprints .ums.ac.id/29659/14/02._naskah_publikasi.pdf

Sugiyono. (2015). Metode penelitian dan pengembangan : research and development. Bandung: Alfabeta. 
Wulandari, E. T. (2015, 06 25). Pengaruh Penerapan Problem Based Learning Terhadap Kemandirian Belajar IPA Siswa Kelas IV SD Se-Gugus III, Kecamatan Temon, Kabupaten Kulon Progo. Retrieved 04 01, 2017, from http://eprints.uny.ac.id/23485/1/SKRIPSI.pdf 